\title{
Traditional Knowledge and Practices Related to Genus Citrus, Garcinia, Mangifera and Nephelium in Malaysia
}

\author{
Dominic Gerten ${ }^{*}$, Idris Salma², Md Sah Muhammad Shafie², Umar Shariah', \\ Pearlycia Brooke ${ }^{3}$, William Wai Wah Wong ${ }^{4}$, Md Harun Norhayati ${ }^{5}$ \\ ${ }^{1}$ Strategic Resource Research Centre, Malaysian Agricultural Research and Development Institute, \\ Bintulu, Malaysia \\ ${ }^{2}$ Strategic Resource Research Centre, Malaysian Agricultural Research and Development Institute, \\ Serdang, Malaysia \\ ${ }^{3}$ Agriculture Research Centre, Department of Agriculture Sarawak, Kuching, Malaysia \\ ${ }^{4}$ Agriculture Research Centre, Department of Agriculture Sabah, Tuaran, Malaysia \\ ${ }^{5}$ Horticulture Division, Department of Agriculture Perak, Bota, Malaysia \\ Email: ${ }^{*}$ gerten@mardi.gov.my
}

Received 7 April 2015; accepted 25 April 2015; published 30 April 2015

Copyright (C) 2015 by authors and OALib.

This work is licensed under the Creative Commons Attribution International License (CC BY).

http://creativecommons.org/licenses/by/4.0/

(c) (i) Open Access

\section{Abstract}

Asia holds massive fruit diversity. Many nutritional and functional properties studies have been done on the fruit species. However, not many studies were done on other aspects of knowledge that can be gained related to these species. The aim of this study was to identify the various uses of the tropical fruit plant species from the genus of Citrus, Garcinia, Mangifera and Nephelium, based on the traditional knowledge and practices of the local communities. The study was conducted through direct interviews with 109 respondents from six areas and communities, targeting the genus Citrus, Mangifera, Nephelium and Garcinia. A total of 18 fruit species were recorded and were categorized into five different purposes, namely for 1) food, 2) medicinal purpose, 3) culture, 4) good practice and 5) other usage. Most of the traditional knowledge related to the fruit species used was as food, food additives or processing method (54.6\%). All species except Citrus spp. and Mangifera laurina have information on traditional knowledge related to food. The highest number of species was recorded from the community of Sibuti, with a total of 14 species recorded while least number was recorded from the community of Bukit Gantang with a total of 4 species. The average number of species and respondents recorded from each community was 8.5 species and 18 respondents. The two most frequently cited species were found to be regional specific knowledge. The most cited species was Mangifera pajang which is endemic to Borneo, while Garcinia atroviridis which recorded the second highest citation was only found in Peninsular Malaysia. Documentation of traditional knowledge is a good tool, not just for the conservation of traditional

\footnotetext{
${ }^{*}$ Corresponding author.
}

How to cite this paper: Gerten, D., Salma, I., Muhammad Shafie, M.S., Shariah, U., Brooke, P., Wong, W.W.W. and Norhayati, M.H. (2015) Traditional Knowledge and Practices Related to Genus Citrus, Garcinia, Mangifera and Nephelium in Malaysia. Open Access Library Journal, 2: e1453. http://dx.doi.org/10.4236/oalib.1101453 
knowledge from being extinct and forgotten, but also to identify new potential, ideas and possibilities from it, so that it opens up to many other scientific studies.

\section{Keywords}

Malaysia, Agrobiodiversity, Tropical Fruits, Traditional Knowledge, Potential Uses, Awareness

Subject Areas: Agricultural Science, Biodiversity, Conservation Biology, Sociology

\section{Introduction}

Asia holds massive fruit diversity of about 500 species distributed in diverse ecosystem [1]. With this rich diversity, only a few species were found to be well-known due to their unique and delicious taste. While the world tropical fruit production was expected to reach 82.1 million tonnes in 2014 [2], it was only being contributed by a small number of crops categorized as "major" and "minor" crops. Thus, there is a need to identify the potential and to promote many other tropical fruit species.

Traditional knowledge (TK) documentation was one of the methods that can be used to identify potentials of certain crops. It also functions as a tool to conserve TK from being lost. The key to a sustainably available TK is by 1) passing the knowledge orally to other members of the community, especially the latter generations, and 2) continuous practice of the knowledge that has been acquired. However, if such action is not being done, the knowledge is exposed to threats and will gradually lose. When the survival of the knowledge is in danger, documentation is the way forward to conserve them. Enhanced documentation of farmers' and users' knowledge, as well as practices on in situ conservation and on-farm management of tropical fruit tree genetic resources will also help in conserving the genetic and species diversity of target tropical fruit species.

The loss of TK is happening all around the world and affects many cultures and indigenous community globally [3]-[7]. It occurred in various rates, depending on a few factors. The major factors were the availability of modern and improved knowledge, technologies and lifestyles in various society, community and region. This modern way of life had caused the society, especially the younger generation to be lack of interest in acquiring TK. It also tends to loss rapidly among the communities in more developed areas or countries as compared with those who came from less developed areas.

Many studies had been done on these tropical fruits species, which involved many fields and disciplines of study. As most of the studies were focused on the well-known or major tropical fruits, not many studies were done on minor, rare, wild or underutilized tropical fruits. Since a couple of decades ago, more and more interests were being given to explore and conserve biodiversity. This brings to more varieties of tropical fruit species being studied and it was found that it was more focused towards their potential from the perspectives of nutritional and functional properties [8]-[11]. Not many studies had been done on traditional knowledge of tropical fruits such as being done by [12], especially from an overall knowledge perspective related to the plant. Most of traditional knowledge studies however only focused on plants with medicinal potential and values [11] [13]-[16]. There was a need to document traditional knowledge on a wider range of species, especially tropical fruit species. Thus, the aim of this study was to identify the knowledge, uses and practices in relation to the tropical fruit plant species from the genus of Citrus, Garcinia, Mangifera and Nephelium, based on the traditional knowledge and practices of the local communities.

\section{Methodology}

\subsection{Study Area}

Six communities were selected for data collection, namely the communities of 1) Bukit Gantang, Perak, 2) Yan, Kedah, 3) Kampung Kakeng, Serian, and 4) Sibuti of Sarawak, 5) Kota Belud and 6) Papar of Sabah. The six locations were selected due to the diversity of either genus Citrus, Mangifera, Nephelium and Garcinia found in the area. The six communities selected were part of the UNEP-GEF Regional Project, of who supported this study to be done on the communities (Figure 1). 


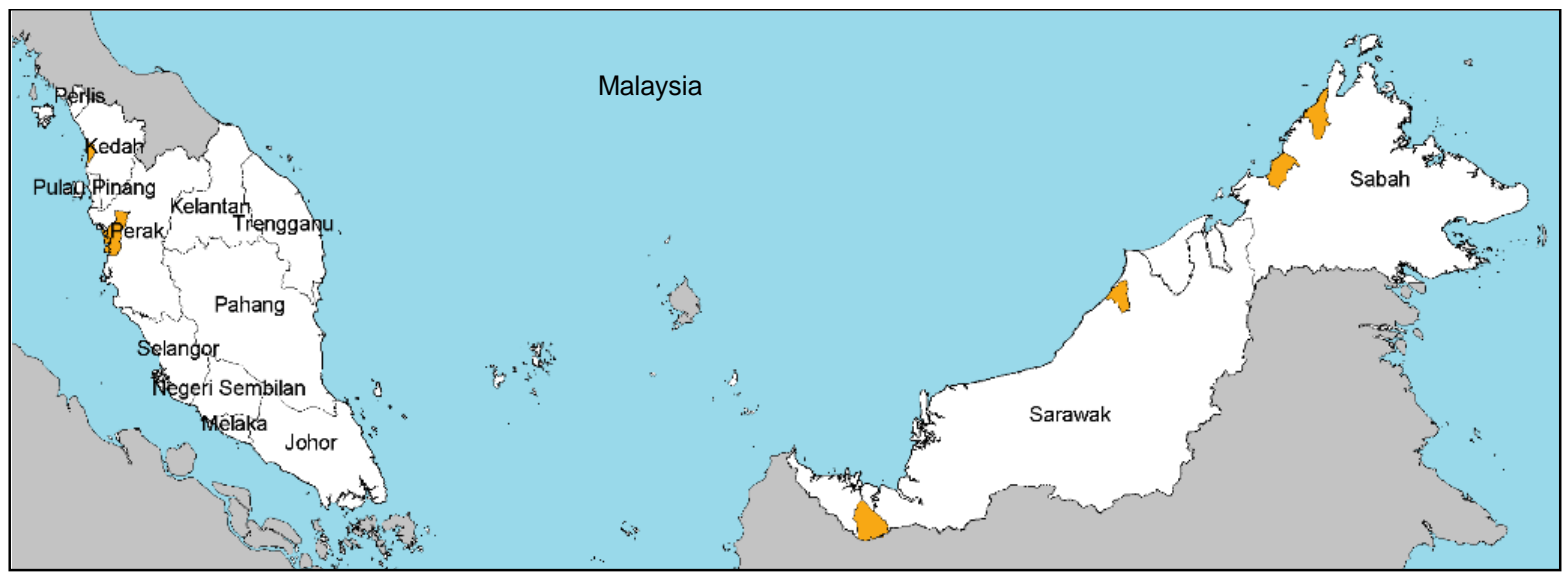

Figure 1. Geographic position of the study areas.

\subsubsection{Yan, Kedah}

Yan District covers an area of 24,177 hectares, at the coordinate of $5.48^{\circ} \mathrm{N}, 00.22^{\circ} \mathrm{E} .40 \%$ of the land was undulated plains and hill terraces while the remaining $60 \%$ were coastal plains. It has an average temperature of $28^{\circ} \mathrm{C}$ $33^{\circ} \mathrm{C}$ and the average annual rainfall of $3288 \mathrm{~mm}$ and respectively, with the wettest month was in October and the driest month was in January.

With a population of 71,918, the people of Yan could boast with Gunung Jerai, the highest mountain in the Kedah. They were mostly rubber tapper, paddy growers, fishermen, government servants and businessmen. The most common fruit species that can be found here were Mangifera foetida, M. indica, Nephelium lappaceum of many varieties and Garcinia mangostana.

\subsubsection{Bukit Gantang, Perak}

Bukit Gantang is a sub-district of Larut-Matang Selama district, in the state of Perak. It is geographically located at $4.47^{\circ} \mathrm{N}, 100.46^{\circ} \mathrm{E}$ and covers land area of 68,160 hectares. It has a hilly terrain is hilly the interior but sloping towards the coastal area. This area has an average temperature of $28^{\circ} \mathrm{C}$, with an average annual rainfall of about $3045 \mathrm{~mm}$.

Bukit Gantang is one of the areas with the abundance of fruits species in the state. Fruit species and varieties which dominate the area were of Nephelium lappaceum, M. indica and G. mangostana. However, Bukit Gantang was also well-known for its production of asam keping, a sliced and dried mature fruits of Garcinia atroviridis.

\subsubsection{Serian, Sarawak}

Serian is located about 60 kilometres to the south of Kuching city, in the Division of Samarahan. Geographically, it is situated at $1.17^{\circ} \mathrm{N}, 110^{\circ} \mathrm{E}$, which ranges from undulating lowlands to mountainous areas. Serian has a high amount of average annual rainfall $(4.074 \mathrm{~mm})$, thus having a climate that ranges from hot and humid to wet and very wet during the raining season.

The district population was 90,763 with about $65 \%$ of the population are from the ethnic of Bidayuh. The other main ethnic groups are Iban, Chinese, and Malay. The vast majority of the people were full time farmers. Serian was blessed with rich native tropical fruit diversity and it could be seen during the fruiting season where the villagers would bring their agriculture and natural products to be sold at the local tamu or farmers market.

\subsubsection{Sibuti}

Sibuti was situated at $4.06^{\circ} \mathrm{N}, 13.8^{\circ} \mathrm{E}$ and one of the sub-districts in Sarawak. Kedayan was the main ethnic that populate Sibuti, followed by Malays, and the majority of them were full time farmers. Sibuti covered an area of $842.47 \mathrm{~km}^{2}$ with topography of undulating land up to hill terraces with a long organic and beautiful coastal plains and beaches. The average temperature in Sibuti was $30^{\circ} \mathrm{C}$ with the average annual rainfall of $2.639 \mathrm{~mm}$.

Sibuti was also found to be rich with tropical fruit diversity, especially from the genus Mangifera. During the fruiting season, the villagers would bring their agriculture and natural products to be sold at the local tamu or farmers market. One of the Mangifera species, the M. caesia was very well-known in Sibuti and many visitors 
from the neighbouring county of Brunei would stop-by at Sibuti to buy the fruits straight from the farmers.

\subsubsection{Papar}

Papar was located at the west coast of Sabah, approximately $38 \mathrm{~km}$ to the south of Kota Kinabalu. The average annual rainfall was $3186 \mathrm{~mm}$ and had an average temperature between $27^{\circ} \mathrm{C}-30^{\circ} \mathrm{C}$, with the wettest month was in November and the driest month was on February. Papar district covered an area of 124,320 hectares and 48\% of the areas were undulated and hilly area and the remaining area was a coastal beach zones.

Having a population of 107,000, most of them were farmers, fishermen or traders. Papar was considered as an agriculture town which boast with rich diversity of tropical fruit, local vegetables and had many fisheries and aquaculture project being done here.

\subsubsection{Kota Belud}

Kota Belud was situated at the west coast of Sabah, about $70 \mathrm{~km}$ from Kota Kinabalu. Having a population of 72,337 in the year 2000, most of them came from the ethnic of Bajau and Dusun, while the rest were mostly Chinese. Located on the $6.21^{\circ} \mathrm{N}, 16.26^{\circ} \mathrm{E}$, it covered an area of $1385.6 \mathrm{~km}^{2}$. The average annual rainfall was $2260 \mathrm{~mm}$ and a range of temperature from $23^{\circ} \mathrm{C}-30^{\circ} \mathrm{C}$, with a dry season from November until March and a wet season from May to September.

The main occupations in Kota Belud are farmers, fishermen, livestock breeders, merchants, civil servants as well as private sector employees. However, agriculture was the main activity in Kota Belud with the main crop produce here were paddy, cassava, sago, coconut, banana and mango.

\subsection{Traditional Knowledge Awareness}

The community was gathered at their respective community or village halls and was given a presentation on Documenting Traditional Knowledge. The aim of the presentation was to create awareness and to educate the communities to document their knowledge. Awareness need to be given to the community to help them realized and understand the global threats of traditional knowledge erosion if no action was to be taken. The community were also advised to document their TK personally, without having to share their knowledge with other people as it was understandably that some knowledge was regarded as a secret for a group of people, family or the community itself.

\subsection{Interviews}

Interviews were done only to interested and volunteered community members that were involved with the project and was willing to share their knowledge for documentation. A Prior-informed-Consent (PIC) agreement was made with the knowledge holder to ensure that the respondent understood the purpose of the documentation and their rights on the knowledge. Documentation was done with the aid of recording devices such as the voice and video recorder. The usage of such device would authenticated the source of the information and served as the only source of reference, as the knowledge holder's own words sometimes might be needed to be translated from their native language. Recorded data was analysed and grouped into categories of uses.

\subsection{Data and Analysis.}

Basically, traditional or indigenous-based knowledge data was analysed and presented descriptively, as the main purpose was to identify knowledge related to the species [11] [12] [16]-[18]. This paper included charts and tables showing a) the categories of uses, b) fruit species with many functions and traditional knowledge among respondents, c) list of species according to their categories of knowledge it relates to, d) number of respondents interviewed and the number of species recorded, and e) list of species most frequently cited by informants. Ratio of the number of respondent to the number of species cited was also determined. Ratio was needed to identify the level of knowledge of each farmer on the targeted species of each site, and comparison was made between each site to understand factors that contribute to its differences.

The cultural significance of each species could be calculated by Cultural Importance Index (CI), whose definition and use are discussed and used in [19] [20], with the following formula:

$$
\mathrm{CI}=\sum_{i=1}^{i=N U} \frac{U R i}{N}
$$


This index also can be seen as the sum of the proportion of informants that mention each species use. The CI was calculated for 1) each site separately and 2) collectively, so that comparison could be made.

\section{Results and Discussions}

A percentage of $34 \%$ out of 316 community members, comprising of farmers, traditional medicine practitioners and local community members were interviewed. This low number of respondent was because only a few had traditional knowledge regarding the six genuses. As was mentioned before, most of the community members had more knowledge on other types of plants such as herbs and medicinal plants rather than tropical fruit plant species. A few of them was also found to be hesitated to share their knowledge because their knowledge are secret to them or their family. A total of 18 fruit species were recorded and its uses were categorized into five different purposes, namely for 1) Food, 2) Medicinal purpose, 3) Cultural, 4) Good practice and 5) Other usage (Figure 2). All five categories were free from uses information overlap, although Food and Medicinal category needed to be carefully distinguished from each other, since some food may have medicinal properties. However, Food category was regarded as any plant parts which can be consumed, in any form consumable (consumed fresh, processed, cooked, as food additives, fed to animal or livestock, etc.). The knowledge includes which parts of plants that could or were safe to be consumed and method of processing the plant parts. Knowledge fall into this category only includes knowledge about which parts of the tree that were edible and how to eat or process them. It does not comprise plant parts that were eaten for medicinal purpose, of which falls under the Medicinal purpose category. Medicinal purpose category contained knowledge on the plant parts that were known by respondents to be nutritious or had healing properties, and if consumed, the main purpose was for its medicinal healing purpose. Cultural category consisted of plant parts that were used in rituals, cultural festivities, and religious ceremony and were part of the community belief system. Good practice category encompassed the knowledge in relation to agricultural practice that had been practiced traditionally and had a potential for up scaling and promotion to other farmers. Good practice category encompassed any traditional agriculture-related practice that had potential for a wider scale usage and could be easily adopted or improved. Good practice category was included as it was the main category that the project needs to identify and highlight. Other usage category includes all other minor knowledge that was unique and only known by few people. Some examples include knowledge of species that was suitable as building material, best source of firewood or as cleaning agent. All the examples can be found in Table 1.

Table 1 showed the fruit species with many functions and traditional knowledge among respondents, which contained the scientific name, vernacular name and its uses. Most of the traditional knowledge related to the fruit species used was as food, food additives or processing method (54.6\%). 31\% of the knowledge were related with medicinal purpose, $13.1 \%$ were related with other usages of the plants, especially in household usage for example, as cleaning agent, furniture, etc. $1 \%$ of the knowledge was identified to be related with cultural practice and beliefs. Only $0.3 \%$ of the knowledge entry showed that there are practices that can be regarded as good

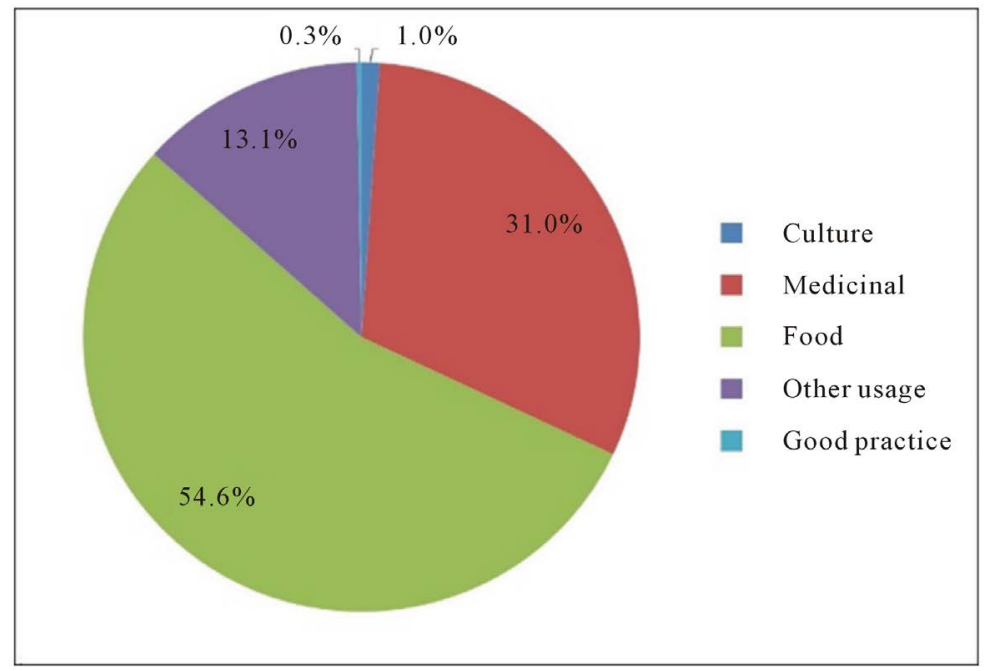

Figure 2. Five categories of uses. 
Table 1. Fruit species with many functions and traditional knowledge among respondents.

\begin{tabular}{|c|c|c|c|}
\hline No. & Species & Local name & Uses \\
\hline 1 & Mangiferapajang & Bambangan & $\begin{array}{l}\text { Fruit: Eaten fresh, ulam*, processed into pickle, as a food additive } \\
\text { (dishes serving fish). Tree trunk: wood for building. etc. Treatment } \\
\text { of scabies, ulcer, winds, etc. }\end{array}$ \\
\hline 2 & Garcinia mangostana & Manggis & Treating vomiting blood, treating piles, family planning, dye, etc. \\
\hline 3 & Garcinia atroviridis & Asamgelugur & $\begin{array}{l}\text { Treat high blood pressure, metal cleaning, food additive for taste, } \\
\text { treat itchiness, etc. }\end{array}$ \\
\hline 4 & Nephelium lappaceum & Rambutan & $\begin{array}{l}\text { Processed into pickles and fruit jam, eaten fresh, source of firewood, } \\
\text { treatment for sore eyes, etc. }\end{array}$ \\
\hline 5 & Citrus aurantifolia & Limaunipis/limaukapas & $\begin{array}{l}\text { Cultural: Spiritual barrier from bad spirits for pregnant women. } \\
\text { Bathing-water mixture. Basic ingredients for rituals. Food: Consumed } \\
\text { fresh. As food additives (esp. Umai**). Drinks. Medicinal: Relieve } \\
\text { body from wind. Eliminate body odour. }\end{array}$ \\
\hline 6 & Garcinia forbesii & Aroi-aroi & $\begin{array}{l}\text { Food or cooking additive, treating stomach ache, relief cough, } \\
\text { post-natal treatment, etc. }\end{array}$ \\
\hline 7 & Mangifera griffithii & Raba & Food: Ulam*. Pickles. \\
\hline 8 & Citrus microcarpa & Limaukasturi & Food: Cooking additives_-eliminates fishy smell of fish. \\
\hline 9 & Citrus spp. & Limau/L. manuk/L. kapur & $\begin{array}{l}\text { Medicinal: Treating headache. Good practice: Knowledge to make } \\
\text { the citrus tree produce sweet fruits. }\end{array}$ \\
\hline 10 & Garcinia parvifolia & Kandis & $\begin{array}{l}\text { Food: Consumed fresh. Cooking additives. Pickles. Medicinal: } \\
\text { To treat cough, sore throat. Post-natal treatment. Treat swelling. } \\
\text { Other utilization: Source of wood for building structure. }\end{array}$ \\
\hline 11 & Mangifera caesia & Binjai/belunu & $\begin{array}{l}\text { Medicinal: Help increase appetite. Treating — cold, body itchiness, } \\
\text { high blood pressure, bronchitis. Food: Consumed fresh. Food } \\
\text { additives. Cultural: Treat mystery itchiness through a ritual. } \\
\text { Other uses: Quality and hardwood source for building structure, } \\
\text { furniture and other woodwork. Dead leafs as good mulch and } \\
\text { fertilizes soil. }\end{array}$ \\
\hline 12 & Mangifera laurina & Mangga air & Medicinal: Treat shingles. \\
\hline 13 & Mangifera odorata & Kuini & $\begin{array}{l}\text { Food: Fresh consumption. Food additives. Processed-Pickle, jam. } \\
\text { Other uses: Source of wood. }\end{array}$ \\
\hline 14 & Mangifera pentandra & Mempelam/pauh & $\begin{array}{l}\text { Food: Processed_-Pickle, jam, chutney. Food additives. } \\
\text { Medicinal: Medicine ingredients in treating piles. } \\
\text { Treat gastric pain. Increase men’s health. }\end{array}$ \\
\hline 15 & Mangifera quadrifida & Rawa/asamkumbang & Food: Fresh consumption. Juice drink. Food additives. \\
\hline 16 & Mangifera spp. & AsamDamaran & $\begin{array}{l}\text { Food: Fresh consumption. Ulam*. As main cooking ingredients } \\
\text { and additives. Other uses: Removes fish slime. Removes oil-stain. } \\
\text { Medicinal: Treat itchyness. Treat winds in babies. }\end{array}$ \\
\hline 17 & Mangifera indica & Mangga & $\begin{array}{l}\text { Medicine: To increase appetite. Treat digestion problem. } \\
\text { Food: Fresh consumption. Ulam*. Fruit juice. }\end{array}$ \\
\hline 18 & Nephelium ramboutan-ake & Pulasan & $\begin{array}{l}\text { Food: Fresh consumption. Cooking ingredients. } \\
\text { Medicine: Treat scabbies and itchiness. }\end{array}$ \\
\hline
\end{tabular}

*Ulam: leaves or fruits that are traditionally eaten raw, usually with rice and/or sambal (a kind of side dish made from chilli and salt or other salty ingredients e.g. shrimp paste); ${ }^{* *}$ Umai: a dish consists of sliced raw fish with mixture of onion, chillies, salt and lime juice.

practice. Table 2 showed whether the species listed and the knowledge related to it had contributed to any of the categories identified. Garcinia forbesii and Mangifera caesia contributed the highest with four categories while Mangiferalaurina and M. quadrifida contributed the least. All species except Citrus spp. and Mangiferalaurina have information on traditional knowledge related to food. Although Citrus spp. and Mangiferalaurina can eaten fresh or be prepared into food, no traditionally-related or unique knowledge can be derived from it from 
Table 2. List of species according to their categories of knowledge it relates to.

\begin{tabular}{|c|c|c|c|c|c|}
\hline Species & Food & Medicinal & Other uses & Culture & Good practice \\
\hline Citrus aurantifolia & $\mathrm{X}$ & $\mathrm{X}$ & & $\mathrm{X}$ & \\
\hline C. microcarpa & $\mathrm{X}$ & & & & \\
\hline C. spp. & & $\mathrm{X}$ & & & $\mathrm{X}$ \\
\hline Garcinia atroviridis & $\mathrm{X}$ & $\mathrm{X}$ & $\mathrm{X}$ & & \\
\hline G. forbesii & $\mathrm{X}$ & $\mathrm{X}$ & $\mathrm{X}$ & $\mathrm{X}$ & \\
\hline G. mangostana & $\mathrm{X}$ & $\mathrm{X}$ & $\mathrm{X}$ & & \\
\hline G. parvifolia & $\mathrm{X}$ & $\mathrm{X}$ & $\mathrm{X}$ & & \\
\hline Mangifera caesia & $\mathrm{X}$ & $\mathrm{X}$ & $\mathrm{X}$ & $\mathrm{X}$ & \\
\hline M. griffithii & $\mathrm{X}$ & & & & \\
\hline M. indica & $\mathrm{X}$ & $\mathrm{X}$ & & & \\
\hline M. laurina & & $\mathrm{X}$ & & & \\
\hline M. odorata & $\mathrm{X}$ & & $\mathrm{X}$ & & \\
\hline M. pajang & $\mathrm{X}$ & $\mathrm{X}$ & $\mathrm{X}$ & & \\
\hline M. pentandra & $\mathrm{X}$ & $\mathrm{X}$ & & & \\
\hline M. quadrifida & $\mathrm{X}$ & & & & \\
\hline M. spp. & $\mathrm{X}$ & $\mathrm{X}$ & $\mathrm{X}$ & & \\
\hline Nephelium lappaceum & $\mathrm{X}$ & $\mathrm{X}$ & $\mathrm{X}$ & & \\
\hline N. ramboutan-ake & $\mathrm{X}$ & $\mathrm{X}$ & & & \\
\hline
\end{tabular}

the aspect of food preparation and its function in food. For example, Citrus aurantifolia can be eaten fresh and be used in food preparation. However, it was also being used as ingredients in a local traditional dish and functions as food additives. Majority of listed species have traditional knowledge that can help to treat illness or for maintaining health, except Citrus microcarpa, Mangifera griffithii, M. odorata and M. quadrifida. The method of treatment using these species varies, from external application such as applied to the skin or to be taken orally such as being in drinks or food. The most well-known treatment identified during the survey was the use of Garcinia atroviridis in treating high blood pressure. The entire informant still practiced the knowledge and claimed that it did reduce their high blood pressure and made them feel healthier. Only a few species was recorded to be used in relation to cultural practices and belief, which were the Citrus aurantifolia, Garcinia forbesii and Mangifera caesia. Citrus aurantifolia was one of the important ingredients in mystical healing rituals. It was used in a mixture, together with other ingredients to help the healer to be able to see visions and identify the cause of the problems or illness. In some cases, the lime was also used as a one of the ingredients in the medicine they prepared. It was also claimed that the species could become a good barrier to protect pregnant women from being disturbed by evil spirits and ghosts. Garcinia forbesii leaves were used together with henna to produce a longer lasting dye on hands and fingers of wedding couples. Henna colouring tradition in weddings was usually done in the Indian and Malay society. An informant in Papar reported that Mangifera caesia tree could be used in a ritual, as a treatment to a mysterious itching sensation felt by patients. It was believed that the tree itself may be the cause of the itching to sensitive individuals, thus a ritual on the tree need to be carried out. This belief may had be based on the basis that the sap itself was found to cause itching when touched and Therefore, any itching felt by the patient may be caused by the tree, although they had no direct contact with the tree. From the study, a good practice on Citrus spp. was identified. The practice was said to affect the tree to produce a sweeter fruit from previously sour fruits. However, this practice can only be done of Citrus tree that was supposed to produce sweet fruits. The practice would have no effect on trees that normally produce sour Citrus fruits. The results of the interviews also found that there are many species that had other uses or functions other 
than as described previously. The other uses were for cleaning brass (G. atroviridis) and copper (G. parvifolia), for dye (G. mangostana and $N$. lappaceum), source of good quality wood (several species), helps to fertilize the soil (M. caesia and M. pajang) and cleaning agent for oil from the skin (Mangifera spp.).

The highest number of species was recorded from the community of Sibuti, with a total of 14 species recorded while least number was recorded from the community of Bukit Gantang with a total of 4 species (Figure 3). The average number of species and respondents recorded from each community was 8.5 species and 18 respondents, with Bukit Gantang had the most respondent involved (26 respondents) and Serian had the least respondent (11 respondents). Although Bukit Gantang had the most respondents, they scored the lowest in number of respondent-to-number of species ratio (1:0.15). This is because many respondents only had the knowledge on very few species. For Bukit Gantang, Garcinia atroviridis was a very common fruit species, and many respondents shared their knowledge on that species while sometimes, it was the only species some respondents had the knowledge about. The highest number of respondent-to number of species was found in Serian (1:0.82), closely followed by Sibuti (1:0.7) and Papar (1:0.64). This high numbers were caused by the respondents of these three sites had more knowledge on a variety of species.

The list of the most frequently cited species by the informants is reported in Table 3 . The two most frequently cited species were found to be regional specific knowledge. The most cited species was Mangiferapajang which is endemic to Borneo, while Garcinia atroviridis which recorded the second highest citation were only found in Peninsular Malaysia. These two species were very well known to the community of respective region and became one of the most sought after fruits during its fruiting season. As the fruits for of both species provide a sourish taste to food, it was widely used as food additives in many modern and traditional recipes and other food product. For G. atroviridis the dishes prepared and aromatized with this G. atroviridis fruit have additional healthy properties other than nutritional qualities. The least cited species were the Citrus microcarpa, Mangifera griffitthii and M. laurina, with one citation each.

Figure 4 lists, in order of importance, the ten most culturally important species from the six sites, according to the $\mathrm{mCI}$, as well as their CI value in each site. In this study, G. mangostana had the highest mCI value of 0.37 followed by M. pajang and $N$. lappaceum with 0.31 and $0.27 \mathrm{mCI}$ value respectively. It was because the collective high number of citation from all sites and it was the only species that was cited by informants from each and every sites. Although G. mangostana rank the highest in collective cultural importance, other species was found to be more culturally important at site specific level, except in Yan. Besides from being famous for its delicious taste and some medicinal and health functions, the community agreed that producing colour dye from G. mangostana peel was the most well-known knowledge for them. In Bukit Gantang, G. atroviridis showed the highest CI value suggesting its deep cultural value. The species was found abundantly available or planted in the area, and it was known that Bukit Gantang was one of the producer of asamkeping or sliced and dried fruit of $G$. atroviridis. Asamkeping was widely used in local dishes, especially in the Peninsular Malaysia or southern Thailand delicacies. Communities of Kota Beludand Sibutivalued M. pajang higher over all other species. Similar to G. atroviridis in Bukit Gantang, the fruit of M. pajang played an important role in local delicacies. They enjoyed the taste and texture of the pulp that was versatile to be prepared into various type food and dishes. The CI value in Papar revealed that G. forbesii was in the top rank, followed by G. mangostana and M. pajang. The

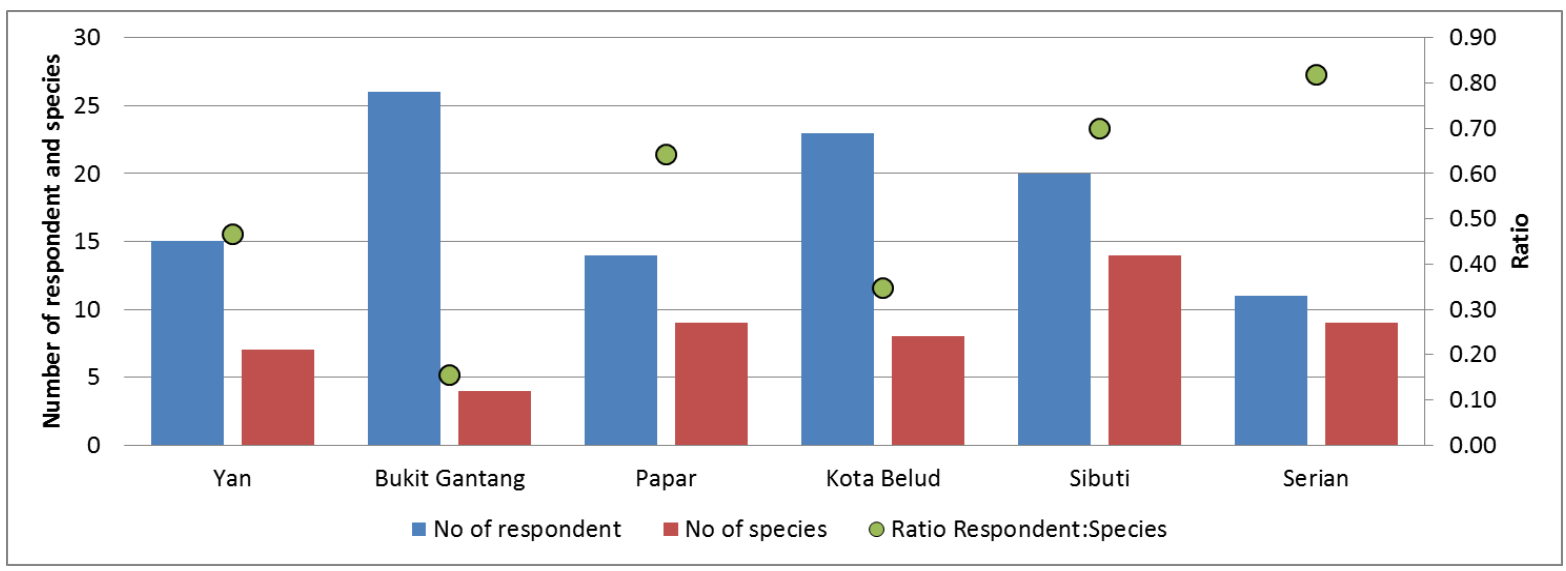

Figure 3. Number of respondents interviewed and the number of species recorded. 
Table 3. List of species most frequently cited by informants.

\begin{tabular}{|c|c|c|c|c|c|c|c|}
\hline \multirow{4}{*}{ Species (alphabetical order) } & \multicolumn{7}{|c|}{ Number of citation of uses for each species } \\
\hline & \multicolumn{2}{|c|}{ Peninsular Malaysia } & \multicolumn{4}{|c|}{ East Malaysia (Borneo) } & \multirow{3}{*}{ Total } \\
\hline & \multirow{2}{*}{$\begin{array}{c}\text { Kedah } \\
\text { Yan }\end{array}$} & \multirow{2}{*}{$\begin{array}{c}\text { Perak } \\
\text { Bkt. Gantang }\end{array}$} & \multicolumn{2}{|c|}{ Sarawak } & \multicolumn{2}{|c|}{ Sabah } & \\
\hline & & & Serian & Sibuti & Papar & Kota Belud & \\
\hline Citrus aurantifolia & & & & 4 & 4 & & 8 \\
\hline C. microcarpa & & & & 1 & & & 1 \\
\hline C. spp. & & & & 1 & & 2 & 3 \\
\hline Garcinia atroviridis & 18 & 54 & & & & & 72 \\
\hline G. forbesii & & & 1 & 4 & 35 & & 40 \\
\hline G. mangostana & 11 & 15 & 9 & 5 & 17 & 1 & 58 \\
\hline G. parvifolia & 1 & & 3 & 10 & & 1 & 15 \\
\hline Mangifera caesia & 3 & & & 7 & 6 & 16 & 32 \\
\hline M. griffithii & & & & 1 & & & 1 \\
\hline M. indica & & & 1 & & 2 & 1 & 4 \\
\hline M. laurina & & & & & 1 & & 1 \\
\hline M. pajang & & & 4 & 16 & 18 & 41 & 79 \\
\hline M. pentandra & 1 & 6 & & 5 & 1 & & 13 \\
\hline M. odorata & & & 1 & 1 & & 4 & 6 \\
\hline M. spp. & & & & 6 & & & 6 \\
\hline M. quadrifida & 2 & & 1 & 1 & & & 4 \\
\hline N. lappaceum & 5 & 4 & 21 & & 1 & 4 & 35 \\
\hline N. ramboutan-ake & & & 3 & 1 & & & 4 \\
\hline Total & 41 & 79 & 44 & 63 & 85 & 70 & 382 \\
\hline
\end{tabular}

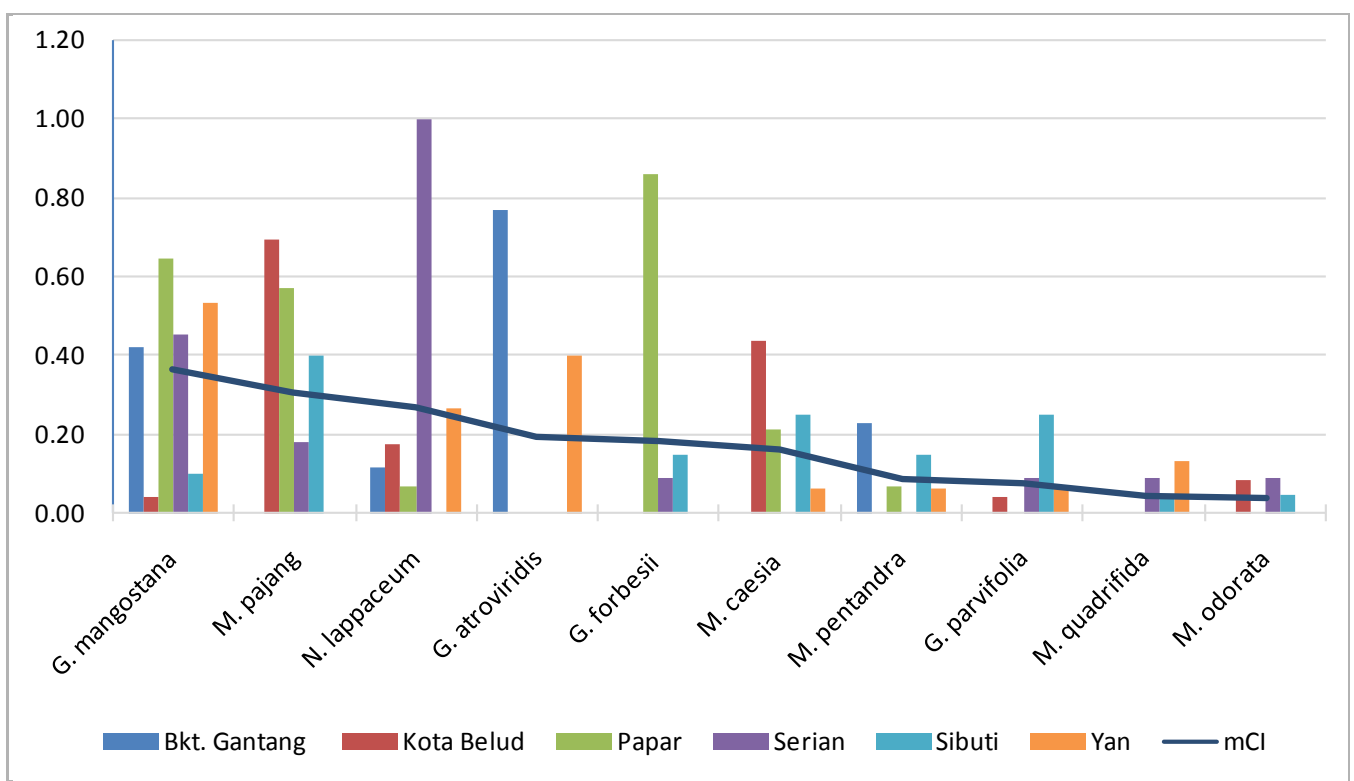

Figure 4. Cultural Importance Index (CI) of the ten most relevant species from the six sites in descending order by mean value (mCI). 
community of Papar appreciated G. forbesii, as its dried fruit peel was widely used in cooking of local dishes and drinks. It was also claimed to have healing properties to cure many illness and diseases, or consumed to maintain general health. Communities of Serian valued $N$. lappaceum, and rank the highest $C I$ value compared to all other species and all other sites. Through a Participatory Rural Appraisal (PRA) survey done in the area, it was found that Serian has the highest diversity of cultivars of $N$. lappaceum. With many of the cultivars were native to the area, some other cultivars were also introduced, resulting its diversity.

\section{Conclusions}

Quite an amount of traditional knowledge with very useful application was discovered from the four genuses. The study showed that the majority of the uses of the species according to their traditional knowledge were less practiced nowadays while some knowledge was no longer practiced and had only become oral knowledge passed from earlier generations. The knowledge was usually practiced by the earlier generation and could only be told to later generation without the opportunity to practically teach them. These decreasing practices can be seen especially where the knowledge was related with traditional medicinal and cultural knowledge. In the case of traditional medical practice, the community trusted more in modern medicine than in traditional medicine. Therefore, the need for traditional medicine and practitioner was decreased. Furthermore, modern medicine was easy to find and had a faster recovery rate. Some traditional medicine even had a complex preparation and time-consuming method. However, traditional healers would be most sought out only whenever an illness was untreatable by modern treatment and became a mysterious illness. As for traditional cultural knowledge, the decrease in practice was found to be caused by the complex supply and preparation of various ingredients and materials for the ritual to be made, as well as the complexity of the rituals itself. This is exacerbated by the reduced confidence in the rituals that were made, especially with more and more people believing more in religion rather than the practices of their ancestors.

During the collection of data, informants generally showed a lack of traditional knowledge on tropical fruit species as compared with other plants especially the herbal species. As compared with herbal plants, informants sometimes need time to reflect and remember the related knowledge on tropical fruit species.

It was found that the knowledge holders were older generations. After the awareness given, they agreed and knew that the threats were real, and appreciated and supported the study and any activities of documenting this knowledge.

Documentation of traditional knowledge is a good tool, not just for the conservation of traditional knowledge from being extinct and forgotten, but also to identify new potential, ideas and possibilities from it, so that it opens up to many other scientific studies. As for the case of tropical fruit species, much potential is still untapped for the benefit of knowledge and development of the agriculture and many other sectors in the country. Similar study needs to be done and widened to other areas, various communities and cultures in the country. Moreover, there is a need for more public awareness of traditional knowledge documentation, especially for tropical fruit species. This may also help communities to help themselves through self-documentation.

\section{Acknowledgements}

The authors would like to extend their appreciation to the community of Bukit Gantang, Yan, Serian, Sibuti, Papar and Kota Belud for the information they shared.

This study is the output of the UNEP/GEF supported regional project "Conservation and Sustainable Use of Cultivated and Wild Tropical Fruit Diversity: Promoting Sustainable Livelihoods, Food Security and Ecosystem Services”, implemented in India, Indonesia, Malaysia, Thailand. The project is coordinated regionally by the Bioversity International in collaboration with Indian Council of Agricultural Research (ICAR), New Delhi; Indonesian Centre for Horticulture Research and Development (ICHORD), Jakarta; Malaysian Agricultural Research and Development Institute (MARDI), Kuala Lumpur; Department of Agriculture (DOA), Bangkok.

\section{References}

[1] Ramanatha Rao, V. and Mal, B. (2002) Tropical Fruit Species in Asia: Diversity and Conservation Strategies. Acta Horticulturae, 575, 179-190.

[2] FAO (2006) Current Situation and Medium-Term Outlook for Tropical Fruits. Sugar and Beverages Group Raw Materials, Tropical and Horticultural Products Service Commodities and Trade Division. Food and Agriculture Organiza- 
tion of the United Nations, Quebec City.

[3] Benz, B.F., Cevallos, J., Santana, F., Rosales, J. and Graf, S. (2000) Losing Knowledge about Plant Use in the Sierra de Manantlan Biosphere Reserve. Mexico Economic Botany, 54, 183-191. http://dx.doi.org/10.1007/BF02907821

[4] Dweba, T.P. and Mearns, M.A. (2011) Conserving Indigenous Knowledge as the Key to the Current and Future Use of Traditional Vegetables. International Journal of Information Management, 31, 564-571. http://dx.doi.org/10.1016/j.ijinfomgt.2011.02.009

[5] Gomez-Baggethun, E., Mingorria, S., Reyes-García, V., Calvet, L. and Montes, C. (2010) Traditional Ecological Knowledge Trends in the Transition to a Market Economy: Empirical Study in the Donana Natural Areas. Conservation Biology, 24, 721-729. http://dx.doi.org/10.1111/j.1523-1739.2009.01401.x

[6] Maffi, L. (2002) Endangered Languages, Endangered Knowledge. International Social Science Journal, 54, $385-393$. http://dx.doi.org/10.1111/1468-2451.00390

[7] Perales, H.R., Benz, B.F. and Brush, S.B. (2005) Maize Diversity and Ethnolinguistic Diversity in Chiapas, Mexico. Proceedings of the National Academy of Sciences of the United States of America, 102, 949-954. http://dx.doi.org/10.1111/1468-2451.00390

[8] Brooke, P. and Lau, C.Y. (2013) Nutritional Value and Economic Potential of Underutilized Mangifera Species in Bungai Area, Sarawak, Malaysia. Acta Horticulturae, 979, 107-115.

[9] Mirfat, A.H.S., Razali, M. and Salma, I. (2013) Antioxidant Properties of Wild Mangifera Species in Malaysia. Acta Horticulturae, 979, 651-659.

[10] MohdShukri, M.A., Mirfat, A.H.S., Erny Sabrina, M.N., Razali, M. and Salma, I. (2013) Nutritional Value and Potential of Malaysian Underutilized Fruits and Traditional Vegetables. Acta Horticulturae, 979, 173-185.

[11] Englbergera, L., Lorennijb, R., Taylorc, M., Tuiac, V.S., Aalbersbergd, W., Dolodolotawaked, U., Tibone, L., Tibonf, J. and Alfredg, J. (2014) Carotenoid Content and Traditional Knowledge of Breadfruit Cultivars of the Republic of the Marshall Islands. Journal of Food Composition and Analysis, 34, 192-199. http://dx.doi.org/10.1016/j.jfca.2012.05.002

[12] Gerten, D., Salma, I., Muhammad Shafie, M.D., Shariah, U., Brooke, P., Wong, W.W. and Nurhayati, M.H. (2014) Traditional Knowledge on Tropical Fruit Plant Species of Six Different Communities in Malaysia. Proceedings of the Seminar Pemuliharaan dan Pemerkasaan Pengetahuan Tradisi, Kepong, 23-24 May 2014, 86-90.

[13] Bradaia, L., Neffarb, S., Amranic, K., Bissatia, S. and Chenchounib, H. (2015) Ethnomycological Survey of Traditional Usage and Indigenous Knowledge on Desert Truffles among the Native Sahara Desert People of Algeria. Journal of Ethnopharmacology, 162, 31-38. http://dx.doi.org/10.1016/j.jep.2014.12.031

[14] Kim, H. and Song, M. (2014) Analysis of Traditional Knowledge for Wild Edible Mushrooms Consumed by Residents Living in Jirisan National Park (Korea). Journal of Ethnopharmacology, 153, 90-97. http://dx.doi.org/10.1016/j.jep.2013.12.041

[15] Tuttolomondo, T., Licata, M., Leto, C., Gargano, M.L., Venturella, G. and La Bella, S. (2014) Plant Genetic Resources and Traditional Knowledge on Medicinal Use of Wild Shrub and Herbaceous Plant Species in the Etna Regional Park (Eastern Sicily, Italy). Journal of Ethnopharmacology, 155, 1362-1381. http://dx.doi.org/10.1016/j.jep.2014.07.043

[16] Zahora, I., Seca, G., Zamri, R., Salmah, O. and Ahmad Nasir, M.Y. (2014) Kajian Penggunaan Tumbuhan Ubatanoleh Masyarakat Melanau di Daerah Kecil Balingian, Mukah, Sarawak. Proceedings of the Seminar Pemuliharaan dan Pemerkasaan Pengetahuan Tradisi, Kepong, 23-24 May 2014, 80-85.

[17] Kala, C.P. (2011) Traditional Ecological Knowledge, Sacred Groves and Conservation of Biodiversity in the Pachmarhi Biosphere Reserve of India. Journal of Environmental Protection, 2, 967-973. http://dx.doi.org/10.4236/jep.2011.27111

[18] GanieAijaz, H., Tali Bilal, A. and Rather Aabid, M. (2013) An Ethnobotanical Study in Budgam District of Kashmir Valley: An Attempt to Explore and Document Traditional Knowledge of the Area. International Research Journal of Pharmacy, 4, 201-204.

[19] Tardio, J., Pascual, H. and Morales, R. (2005) Wild Food Plants Traditionally Used in the Province of Madrid, Central Spain. Economic Botany, 59, 122-136. http://dx.doi.org/10.1663/0013-0001(2005)059[0122:WFPTUI]2.0.CO;2

[20] Pardo-de-Santayana, M., Tardio, J., Blanco, E., Carvalho, A.M., Lastra, J.J., Miguel, E.S. and Morales, R. (2007) Traditional Knowledge of Wild Edible Plants Used in the Northwest of the Iberian Peninsula (Spain and Portugal): A Comparative Study. Journal of Ethnobiology and Ethnomedicine, 3, 27. http://dx.doi.org/10.1186/1746-4269-3-27 